\title{
Fiscal and economic aspects of book consumption in the European Union
}

\author{
Karol Jan Borowiecki ${ }^{1}$. Trilce Navarrete ${ }^{2}$
}

Received: 21 June 2017/ Accepted: 5 September 2017/Published online: 20 October 2017

(C) The Author(s) 2017. This article is an open access publication

\begin{abstract}
One of the available and yet controversial tools in cultural policy at the national level is the reduction of VAT rates for cultural goods and services. We document the standard and reduced VAT rates in EU-28 countries in the period from 1993 to 2013 and explore the underlying determinants. We further introduce a simple theoretical framework to explain how reduced fiscal rates are expected to decrease prices and increase quantities of the consumed cultural goods and services. We then estimate quantitatively that a decrease in the VAT rate for books by one percentage point is associated with an economically significant drop in the price by $2.6 \%$. Finally, we show the positive effect of a fiscal rate reduction on the book expenditure, where a one percentage point decrease in the VAT rate for books leads to an increase in expenditure by $2.7 \%$.
\end{abstract}

Keywords Cultural consumption · Book markets · Cultural policy · Value added tax $\cdot$ Fiscal policy

JEL Classification H21 - H31 - I30 - K34 - Z11

Trilce Navarrete

navarrete@eshcc.eur.nl

Karol Jan Borowiecki

kjb@sam.sdu.dk

1 Department of Business and Economics, University of Southern Denmark, Campusvej 55, 5230 Odense M, Denmark

2 Erasmus School of History, Culture and Communication, Erasmus University Rotterdam, Burgemeester Oudlaan 50 - room M7-02, P.O. Box 1738, 3000 DR Rotterdam, The Netherlands 


\section{Introduction}

Cultural consumption is associated with positive externalities. Those who read books, go to theatre or attend music concerts, do not only increase their own utility, but generate also positive effects for the society, for example, in the form of improved education and literacy. Welfare theory informs us about the existence of dead-weight if goods and services that incorporate externalities are consumed. This is caused by the fact that markets do not internalize externalities and thus trade does not occur at efficient quantities. Therefore, the action of policy makers is required so that the right quantities are supplied and consumed. An economics textbook solution to this inefficiency is fiscal policy: by the means of taxes and subsidies consumption of cultural goods and services can be steered so that efficient outcomes are obtained. There is, however, little understanding of these measures, especially of fiscal discounts in the European context, and there is also only limited agreement on whether these tools should be used.

This paper attempts to fill this void by documenting fiscal rates across the EU Member States over time, including rates for cultural goods, by analysing the local context (i.e. population, GDP). The goal of this paper is to improve our understanding of fiscal rates for cultural goods and services, with a particular focus on books. This is done by documenting discounted value added tax (VAT) rates across EU Member States from 1993 and by illuminating the effects of fiscal incentives on the prices of selected cultural goods and services and on the cultural expenditure of households on books. Governments in Europe can chose to lower the VAT for books in order to stimulate an increase in literacy, as did the Netherlands lowering the tax for books from 21 to $6 \%$, or Ireland from 21 to $0 \%$, or Sweden from 25 to $6 \%$.

Tax literature has raised concerns on the efficiency of VAT for culture as they are considered "expensive and poor targeted means of addressing distributional concerns" (Borselli et al. 2012, p. 14). As indirect subsidy, VAT is less visible as it is not formally discussed in parliament (Hemels 2009). These concerns become more critical with the expanding international online markets and as new Member States homogenize fiscal practices. The reduced rates as a whole are regarded as a revenue loss of up to $1.7 \%$ of the share of GDP (CE 2007). Reduced VAT rates for culture are a significant cost and as such are included as tax expenditure in national budgets (O'Hagan 2003). Arguments to support the implementation of a VAT rate for culture focus on the positive externalities that come with cultural consumption (EC 2014; Frey 2008). By consuming culture, self-interested individuals provide benefits to society as a whole, be it in the form of improved education or literacy (Krashen et al. 2012) or as higher consumption of goods and services offered during cultural consumption (e.g. purchases in the museum café) (Plaza 2000).

An important international comparative analysis on fiscal policy to support the arts was conducted more than three decades ago and focused on tax breaks in the USA (Feld et al. 1983). The model of tax concessions for cultural goods and services in Europe is introduced and analysed economically in an important study by O'Hagan (1998), while Schuster (2006) provides insights on tax incentives in 
cultural policy with a particular focus on the USA. Recent publications on cultural VAT rates include country analysis to estimate consumption as a result of changes in the fiscal policy (Gesko 2013; Hjorth-Andersen 2000; MvF 2014; PrietoRodriguez et al. 2005; Ringstad and Løyland 2006), to focus on the nature of the policy (Campbell 2013; Colbjørnsen 2014; Hemels 2009), or to estimate the revenue raised by the VAT (O'Hagan 2003). Publications on the relationship between pricing and cultural consumption remain dissociated from VAT rate policy.

This article contributes to the body of work on the economic analysis of fiscal policy by comparing the VAT rates in all EU Member States for the last two decades and by adding country-specific determinants to the analysis of cultural consumption. That is, we not only analyse the changes in VAT rates and their effect on book prices in time, but we also examine the association with cultural consumption. Specifically, we look at the standard and reduced VAT rates for cultural goods in EU Member States from 1993 to 2014. Since VAT rates are part of a national tax policy, not all Member States have the same reduction on specific types of goods and services, and most, but not all, countries have introduced reduced rates in different years. These geographical and temporal variations offer a very convenient setting that can be exploited quantitatively; in doing so, we shed light on the determinants of fiscal rates. One key finding is that the VAT rates are not related to the fundamental variables that determine cultural consumptionnamely GDP, level of education and population size-but instead appear to be set following a different rationale. This seems to question the notion that cultural tax discounts are used to stimulate cultural consumption. The paper also explores how reduced cultural rates affect book prices and household expenditure. Indirectly, our results contribute thus to research on price elasticity in the arts. We show that these associations are in accordance with theory and demonstrate also that an increase in VAT rates for books has a causal influence on book consumption.

The book angle is also particularly interesting in light of current policy developments. France and Luxembourg were two EU countries that introduced a reduced VAT rate also for e-books from 2012, at 5.5 and 3\%, respectively. This was done, however, without the Commission's approval and, as a result, in 2015, the Court of Justice of the European Union ruled that e-books supplied via download or streaming are a service and therefore fall outside of the VAT exemption. The VAT rate is established based on the carrier and not on the content, resulting in a negative incentive for technologic development in Europe. This appears in stark contrast to the substantial support and funding into the improvement and promotion of Europe's digital cultural heritage. Not surprisingly, in March 2017 a last amendment is discussed in the Council of Europe which would enable the introduction of reduced (and super reduced) VAT rates for electronic books (albeit not for music or video content in general). This amendment would form a key element in the enabling of the Digital Single Market Strategy for Europe. ${ }^{1}$ It is hoped that the here disclosed enhancing role of VAT rate discounts on consumption of books will

\footnotetext{
1 This development finds support in the positive effects of a lower VAT rate on book consumption which is disclosed in the underlying paper. Furthermore, these fiscal revisions are in line with the arguments made by the authors' of the underlying study during presentations at various policy briefing workshops in Brussels and in other places over the period from 2015 to 2016.
} 
contribute further to related discussions in the future. In general, the overall role of digital technologies in increasing cultural consumption has to be acknowledged as well (e.g., Borowiecki and Navarrete 2017; Navarrete and Borowiecki 2016), albeit is addressed in this paper only incidentally.

At the EU-level, decision-making on cultural fiscal rates is conducted by the taxation departments, which have likely divergent aims and priorities than the department responsible for cultural policies. The extended period considered here allows for a potentially rich insight into policy analysis and, in this way, we bridge the gap found between fiscal policy and cultural policy. It is hoped that results from this analysis will contribute not only to the research on public economics (fiscal studies) and cultural economics, but also to fiscal policy, particularly regarding the use of tax discounts as indirect support to the arts across EU Member States.

This paper is organized as follows. Section 2 introduces VAT as an instrument used to collect revenue and as a policy tool to incentivise a desired behaviour. Section 3 reviews the empirical studies in Europe aimed at documenting the change in prices and in consumption brought on by a reduced or increased VAT rate. Section 4 presents the theory, followed by Sect. 5 where the data are presented. In Sect. 6, we describe our analysis. Section 7 concludes and proposes future research.

\section{VAT reduction as government support of culture}

Governments support the production, distribution and consumption of arts and culture through direct financing, generally in the form of grants and subsidies to organizations and sometimes through consumer vouchers. An alternative form of government support is defined by tax policies in the form of indirect subsidies, of which two common examples include tax deductions for private supporters of the arts and culture or the reduction of the VAT rate for cultural goods and services (O'Hagan 1998; Linklater 2014; Hemels 2005). This paper focuses on the last modality.

VAT is first of all a form of revenue collection by the government (Schuster 2006), accounting for an average of $7.9 \%$ of the GDP and $22.3 \%$ of total fiscal revenue in the EU in 2012 (Eurostat 2014, pp. 179-180), whereby a tax is collected every time value is added to the production process of a good or a service. Successive taxpayers can further deduct input tax on purchase while reporting output tax on sales, so that finally the tax collected by the tax authorities should equal the VAT paid by the final consumer to the last vendor. VAT collection, as other tax forms, can also have an auxiliary or subsidiary function such as redistribution of wealth or influencing market behaviour (Hemels 2009). A reduced VAT rate thus represents a decrease in government revenue that could otherwise be allocated to support the non-profit sector and increase equity of services. Instead, it is the consumer who actually decides how resources are being spent when selecting specific goods or services with a lower VAT rate; for instance, in the case of cultural goods or services.

Because indirect subsidies work as an incentive towards a desired behaviour by lowering the tax rate (or as a disincentive for consumption by setting a higher tax 
rate) (Schuster 2006), governments can reduced the VAT rate to encourage an increase in the demand for specific goods. An increased consumption of books, for instance, due to a discounted VAT rate would further deliver positive externalities associated with education and literacy. However, and because of their indirect nature, reduced VAT rates cannot be specifically directed towards a desired good (e.g. all books receive a reduced VAT rate), provider (e.g. all public and private producers), or consumers (e.g. all genders, ages and socio-economic background). In this way, reduced VAT rates have been criticized for being an ineffective means to support cultural consumption, particularly as it ignores the consumer's ability to pay. However, the fact that each EU Member State can choose to reduce VAT for one or another good makes it an important element in the national cultural policy (Appendix 1 provides further details on the VAT Directive of the European Union including the recent amendments).

The government bodies that define the fiscal policy in a country are not the same as those who set the cultural policy. This results in a cultural policy defined by a fiscal logic (Schuster 2006). The fragmented approach to defining VAT rates as part of a national policy, particularly when including digital culture, has recently been criticized: "newspapers are commonly placed within a media policy sphere, whereas books (print and digital) are typically treated within a cultural policy framework. Moreover, policy frameworks for media business and technology development are often seen in light of competition and innovation policies, thus evoking a different set of policy aims and motivations" (Colbjørnsen 2014, p. 4).

\section{Reduced VAT rates in the European Union}

What follows is a revision of empirical research on the effect of a change in the VAT rates.

\subsection{General VAT: revenue estimations and rationale for use of VAT}

VAT is a system by which the state gathers resources. In 2012, the countries of the EU-28 reported collecting $22.3 \%$ of their total taxation through VAT representing an average of $7.9 \%$ of their total GDP (Eurostat 2014).

The rationale to lower the VAT rates for cultural goods is often based on a merit good argument, where the government intervenes by giving indirect support to broaden demand (CE 2007). There are further rationales to lower VAT rates. In the Netherlands, books receive a reduced VAT rate on the basis of their cultural and educational value, and therefore educational books on CD-ROM and DVD also have a lower VAT rate (6\%) (Hemels 2007). However, books on tape and downloaded e-books have the regular VAT rate (21\%) (Belastingdienst 2014). Similarly, Slovakia reduced the VAT rate on books in order to increase the production and consumption of literature in the national language and so improve the overall educational level (Gesko 2013) while Sweden reduced their VAT to lower prices and promote readership, quality of books, and variety of content (CE 2007). Increasing equal access goods and services, particularly to lower income 
groups, is also an argument for a reduced VAT rate (Linklater 2014; Borselli et al. 2012), though a VAT cut confers a greater (proportional) benefit on wealthier households because they consume more to begin with (Crossley et al. 2009, p. 13; Blundell 2009; Dallongeville et al. 2010; Hemels 2005).

\subsection{Supplier behaviour: passing on the cost reduction to consumer prices}

A lowering of the VAT rate would lead to a lowering of the price due to a reduction in the cost to the supplier. This was the case in Sweden, where a reduced VAT rate for books from 25 to $6 \%$ led to a decline in book prices of $16 \%$ after one year while sales increased for publishers (16\%) and for retailers (20\%) (Ahlmark 2003). In this case, the lower VAT rate benefited the retailers who received greater profits due to the increase in sales, reported at $4 \%$ in 2003 after covering major ICT investments (Ahlmark 2003, pp. 12-13). In addition, the lower VAT and increase in sales benefited publishers, who invested in the production (and sale) of greater variety and quality books, including an increase in the production of specialized books (Ahlmark 2003, pp. 5-6). Though changes in price are well documented, changes in quality are not. Hence a perceived price increase may miss the quality change behind it. The Swedish case may be unique since the lowering in the VAT rate benefited from large communication campaigns, which made it difficult for suppliers to avoid lowering prices.

If the VAT reduction is not passed on to the price, the benefit will appear in company profits, rather than in the consumer's disposable income. Providers do not always pass on the cost reduction to the consumer, particularly when the VAT reduction is perceived to be temporary (CE 2007). An example of this can be found in Germany, when a lower tax rate for the hotel industry in 2010 did not lead to lower bed fares (Lomas 2010).

An increase in the VAT rate for theatre tickets in the Netherlands from 6 to $19 \%$ led to an increase in prices (representing a consumer price index increase from 124 to 140), in some cases before the actual VAT rate change. A year later, the VAT rate was changed back to the original reduced rate $(6 \%)$, yet prices did not decrease accordingly (the consumer price index changed from 137 to 134) (Statistics Netherlands 2015). A follow-up study conducted by the Dutch Ministry of Finances found that the $12.3 \%$ price increase resulted in a $3.9 \%$ reduction of ticket sales in the short term, and a $4.5 \%$ reduction in the long term. The decrease in demand, according to the study, was found to be part of the general economic recession that started in 2008, rather than a direct result of the short-term change in VAT (MvF 2014).

In Slovakia, a VAT rate reduction for books in 2007 did not result in a lower book price, as observed by Gesko (2013). The VAT rate reduction (from 19 to 10\%) did not lead to an increase in consumption because, as Gesko argues, the overall household income was relatively low, the VAT rate decrease was relatively small, and the share of expenditures on books compared to other goods was low, even if there were not relevant substitutes for books at the time. Book prices, instead, rose at a higher rate than inflation. 
Labour intensive services tend to change prices more dramatically when the VAT is increased, according to Carbonnier (2005). This is because decreasing production in order to accommodate to a higher price is much easier than increasing production in response to a lower VAT. As an example, Carbonnier compares the prices of books and home repair services around the 1999 and 2000 French VAT reforms. Though book prices did change accordingly, the change was less dramatic than for labour intensive services. These findings may be relevant when used to analyse labour intensive cultural activities.

Prices for books, argue Franssen and Velthuis (2014), continue to be largely determined by genre as a rudimentary measure of quality and by the material qualities of number of pages, binding and size of the book. Prices are set not by production cost (a run of 3000 books cost $€ 1.64$ per book) but by expectations in the market. Their historical analysis did not mention the changes in VAT rates for books in the Netherlands yet their results point to a pricing strategy independent from the national fiscal policy.

\subsection{Consumer behaviour: responding to a price change}

Government intervention in the form of a VAT rate change in the long-standing EU Member States has an overall impact on consumption. Increases in consumption following the VAT change in six countries showed that a higher VAT rate would lead to a decrease in consumption (Blundell 2009).

When comparing the change in demand as a result of a reduced VAT rate or the distribution of vouchers (e.g. food stamps), a study found that a lower VAT rate was the most effective instrument. The study developed an economic model that estimated an increase in demand following a VAT rate reduction on fruits and vegetables from 5.5 to $2.1 \%$. The lower consumer price led to an increase in consumption, and the extent of the effect depended on the initial level of consumption and on the price demand elasticity, so low-income consumers benefited less. In contrast, vouchers increased consumption only on the targeted population (Dallongeville et al. 2010).

Studies on consumer response to changes in the price of cultural goods are very rare and typically restricted to analyses of single countries. ${ }^{2}$ The only study that has explicitly linked fiscal issues and cultural consumption, of which we are aware, is by Prieto-Rodriguez et al. (2005). The authors focus on Spain and find that a $1 \%$ change in household expenditure results in a $1.75 \%$ change in cultural goods expenditure, while expenditure on books changes by $1.37 \%$. Contrary to expectation, books were found to be complementary to performing arts and other cultural goods. Prieto-Rodriguez et al. (2005) also found that more welfare was gained with a VAT rate decrease, especially so for the population with a higher socio-economic level. The income elasticity for books in Spain was found to be 1.65. A similar result was found in two studies of the book market: in Denmark the income

\footnotetext{
2 There are several important studies on the consumption of cultural services such as the research on museum attendance. However, also this research is either theoretical (Prieto-Rodríguez and FernándezBlanco 2006; Frey and Steiner 2012) or constrained to single countries (e.g., Kirchberg 1998 for German museums; O’Hagan 1995 for Irish libraries).
} 
elasticity was 1.97 (Hjorth-Andersen 2000) and in Norway it was 1.3 (Ringstad and Løyland 2006). The price elasticity was found to be well below -1 across all three studies.

A study of the Norwegian book market further found that geographical access to paper books influenced the likelihood of consumption, so that big cities with many bookstores had a higher demand. Households with children 7 through 19 years old, single person households or households with a higher income were more likely to buy books (Ringstad and Løyland 2006). Similarly, in Sweden, the reduced VAT was reported to have had a greater benefit in larger urban centres (Ahlmark 2003, p. 14). Canoy et al. (2006) report a comparable result where countries with a higher number of public libraries had a higher number of book loans and higher percentage of reading popularity. Canoy et al. (2006) focus on book title production and conclude that the book industry does not need government intervention, though possible instruments include special VAT rates for books, prizes and grants for authors, and support to public libraries.

Cultural demand is typically found to be driven by three fundamental determinants (e.g. Borowiecki 2015): the size of demand (usually measured in relation to population size), the purchasing power (approximated with wages or GDP per capita indicators) and human capital (i.e. the level of education). The level of education is an important determinant for book demand (Canoy et al. 2006), even stronger than income, though the effects of the two variables are not easy to separate (Seaman 2006). Ateca-Amestoy (2008) further identifies women, urban, single and regular cultural consumers as sub-groups within the population that are more likely to be cultural consumers. Such determinants, such as age, gender, past exposure to the cultural form, lifestyle determinants and ethnic background are not consistently found to determine consumption across empirical studies, according to an overview of applied research on cultural demand conducted by Seaman (2006). Political affiliation, as an alternative determinant, is found to have little effect on the reading behaviour in Russia (Zavisca 2005).

Lazzaro and Frateschi (2015) note visits to the library to be an individual activity, unlike social activities such as cinema, theatre or museums. Public libraries provide access to their holdings free of charge, though may charge a membership for lending books, and may provide a number of information services and literacy courses. Individuals visit libraries primordially for reading books that are purchased by the library; consequently, governments subsidize libraries to compensate for the crowding out effect (Towse 2010). Book consumption, the topic and focus of this contribution, relies on the purchase of the good by the individual.

\subsection{Beneficiaries of a reduced VAT rate for books}

From the previous sections it can be concluded that the beneficiaries of a reduced VAT rate and book price include the book publishers, who are able to produce greater quality, variety, and specialization following a rise in revenues. Book retailers also benefit by the increase in sales and can further improve their position in the market. In the case of Sweden (Ahlmark 2003), retailers invested in ICT and a 
number of new selling points were recorded, reflecting an increase in the market share. Long-term changes have yet to be reported.

Consumers also benefit, by being able to afford more, better and more costly books than before, as in the case of especially urban Sweden. There is little evidence of non-readers becoming readers following a reduction in the VAT rate of books. A price reduction from lower VAT rate may be one element that strengthens the position of books in society (Ahlmark 2003, p. 29), but that has to be used in combination with cultural policy.

The government is perhaps the only negatively affected party, as a reduced VAT rate represents an expenditure and a reduction of resources that could otherwise be directed to specific goals.

\section{Theoretical effect of a change in VAT on prices and well-being}

Reading has a direct effect on improved reading abilities such as reading comprehension and spelling, which in turn are associated with a general positive performance at school (Mol and Bus 2011). Access to books has also long-term benefits such as increasing vocabulary, background knowledge and comprehension skills (Newman and Moland 2016). Reading and literacy enable individuals to process information that will lead to intelligent decision-making, vital in our society, through the identification of information sources, assessment and organization of the information, and use of the information in critical thinking and problem solving (Doyle 1992; Bruce 1997). Governments recognize the benefits of reading and support policies that facilitate access to print material. Lowering the VAT tax on books is such a policy.

The effect of a tax reduction on the price and quantity of a good in a competitive market is shown in Fig. 1. In a tax-free world, the intersection of the supply and demand functions deliver the efficient equilibrium quantity $Q^{*}$ and price $P^{*}$ of the good consumed. Imposing a standard VAT rate on a good or service shifts the supply curve upwards, increasing the price to $P_{\text {standard rate }}$, decreasing the quantity to $Q_{\text {standard rate }}$ and creating a welfare loss of the size of the shaded areas $A$ and $B$. The welfare loss exists because there are certain quantities which the supplier would be willing to produce and the customer would be willing to pay for (i.e. where the demand function lies above the supply function), but these quantities are not exchanged because of the price distortion created by the fiscal burden. Lowering the standard tax rate to the reduced rate will shift the supply curve downwards towards the efficient equilibrium. A fiscal reduction results in a decrease in the price to $P_{\text {reduced rate }}$ and an increase in the quantity to $Q_{\text {reduced rate }}$ and leads to a lower welfare loss to society (area B only). ${ }^{3}$

\footnotetext{
${ }^{3}$ Changes in demand are determined by (1) the existence of substitutes, (2) the level of disposable income, (3) the share of expenditure on a good, (4) the size of the tax change, and (5) the nature of the need for the good (e.g. imposed demand as in the case of students using books). A tax reduction may have an income effect, arbitrage effect or substitution effect (Barrell and Weale 2009).
} 


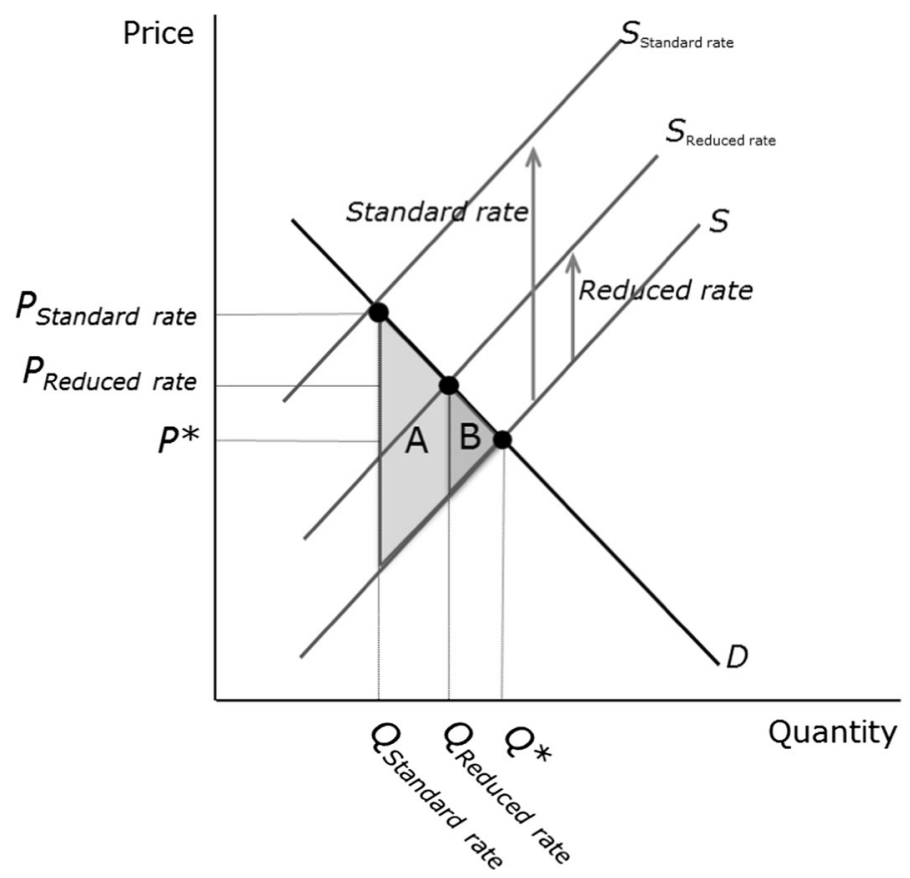

Fig. 1 Effect of reduced VAT rate

\section{Data sources and preliminary overview of the data}

This research is based on data obtained mainly from four sources. First, VAT rates applied in the EU Member States are obtained from the European Commission Taxation and Customs Union. The available data cover the period from 1993 to 2014 and constitute the core of the fiscal data. Member States report the standard and reduced rates for a wide range of goods and services. When multiple reduced rates were reported, the lowest for a given category was used.

Second, data on prices of cultural goods for the period 2003 to 2013 are obtained from the ERICarts Compendium of Cultural Policies and Trends (Compendium 2015). This series documents the regular price of a specific cultural product, for example a best-selling book, across countries. These are regular list prices and it has to be noted that actual prices (especially in countries without resale price maintenance) may be lower. ${ }^{4}$

Third, Eurostat statistics are used as the source of socio-demographic data for the period from 1993 to 2013, which includes population size, GDP per capita and educational attainment. We also obtain records on household expenditure from the latest available Eurostat Cultural Statistics (2011). In some analyses, we avail ourselves of the Eurostat Community Survey on ICT usage in households and by

\footnotetext{
4 An implicit advantage of looking at list prices is that book prices for individual titles may fluctuate over time, which would make a comparison rather difficult.
} 
Table 1 Summary statistics

\begin{tabular}{lcrr}
\hline Variable & Observations & Mean & $\begin{array}{r}\text { Std. } \\
\text { dev. }\end{array}$ \\
\hline Standard VAT rate & 450 & 19.84 & 2.83 \\
VAT rate for books & 450 & 7.08 & 6.01 \\
VAT rate for admission to cultural services & 447 & 6.76 & 7.45 \\
Left-wing party & 359 & 0.40 & 0.49 \\
Log (population) & 423 & 16.06 & 1.44 \\
GDP per capita & 416 & 23.47 & 13.01 \\
Share of medium or high educational attainment (ages 15-64) & 416 & 64.47 & 15.61 \\
Price of book & 170 & 21.01 & 7.84 \\
Price of film ticket & 182 & 7.49 & 2.40 \\
Price of museum ticket & 174 & 6.45 & 3.63 \\
Price of opera ticket & 180 & 41.80 & 30.15 \\
\hline
\end{tabular}

individuals in 2008 (Eurostat 2015). These records are used to analyse the relation between VAT book rate and Internet commerce for books.

Finally, we use World Bank data on political orientation (Keefer 2012). This appears to be the dataset that best enables comparison across multiple Member States. Below is an overview of the data analysed.

Table 1 shows a summary of the underlying data, including fiscal rates, prices of cultural goods and services and basic socio-economic control variables. ${ }^{5}$

A first analysis was conducted to compare the changes in general VAT rates and reduced VAT rates for books across Member States. Figure 2 shows the average standard VAT rate for the EU (see country-specific figures in Appendix 2). The standard VAT rates are shown in the blue plotted line for the EU-28 and in the red plotted line for the EU-12. The red vertical lines mark the growth of the EU: the enlargement to EU-16 in 1995 with the accession of Austria, Finland and Sweden, followed by the EU-26 in 2004 with the accession of Cyprus, the Czech Republic, Estonia, Hungary, Latvia, Lithuania, Malta, Poland, Slovakia and Slovenia, and culminating in the current EU-28 from 2007 with the accession of Romania and Bulgaria. The overall increasing trend can be related both to the accession of Member States and to increases within countries. A noticeable increase in the standard VAT rates can be observed after 2010, presumably caused by the need to finance the expensive economic stimuli that were introduced in the aftermath of the financial crisis of 2007-2008.

\footnotetext{
5 In the countries and years covered, the mean VAT standard rate is found at $19.8 \%$, while the VAT rate for books is $7.1 \%$ and the VAT rate for admission to cultural services is $6.8 \%$. These averages are based on 450 observations, which are based on annual observations for each country which was member of the European Union. The mean price is 21 euros for a book, 7.5 euros for a film ticket, 6.4 euros for a museum ticket, and 41.8 euros for an opera ticket. During the time period covered the Member States have a population size of 16.1 million on average, a GDP of around 23,470 euros per person, and around $64.5 \%$ of their population aged 15-64 has medium or high educational attainment.
} 


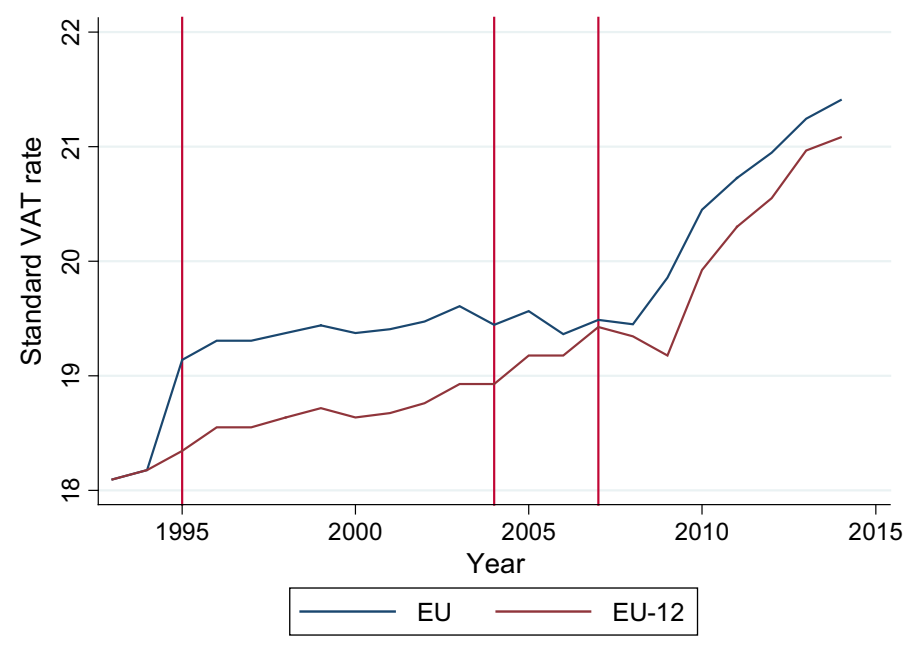

Fig. 2 Standard VAT rate, average. Note vertical lines mark the years of accession of new Member States to the European Union. The enlargement to EU-16 in 1995 marks the accession of Austria, Finland and Sweden, to EU-26 in 2004 with the accession of Cyprus, the Czech Republic, Estonia, Hungary, Latvia, Lithuania, Malta, Poland, Slovakia and Slovenia, and to EU-28 in 2007 with the accession of Romania and Bulgaria. For sources, see text

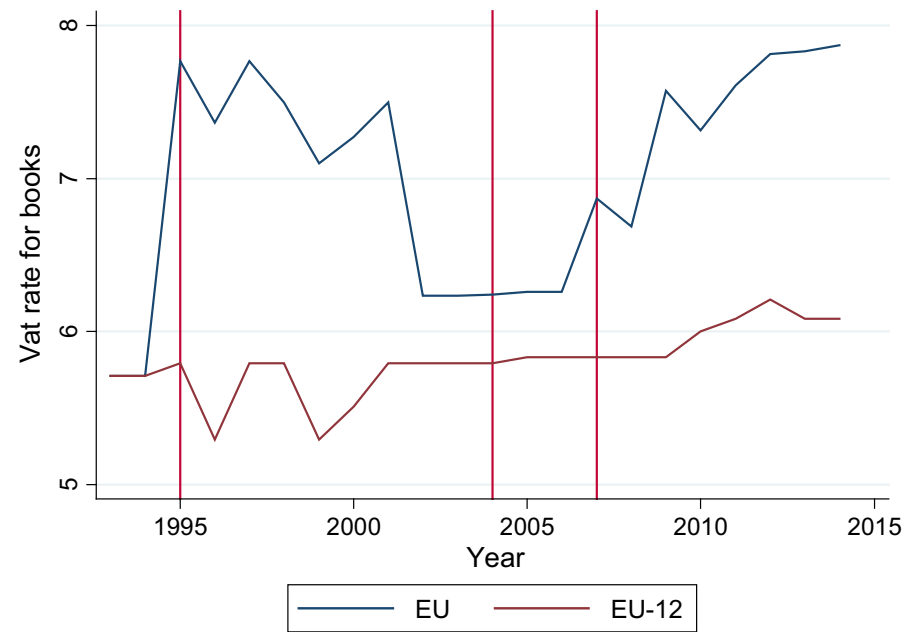

Fig. 3 VAT rate for books, average. Note vertical lines mark the years of accession of new Member States to the European Union (see Fig. 2 notes for details). For sources see text

The average VAT rate for books in the EU is shown in Fig. 3. The red plotted line represents the EU-12, with a relatively stable VAT rate for books, while the blue plotted line includes the current EU of a given year. The average for all Member States increased after the 1995 enlargement, which later gravitated towards the average of the EU-12. Since then, the trend has been rising due to both accession 


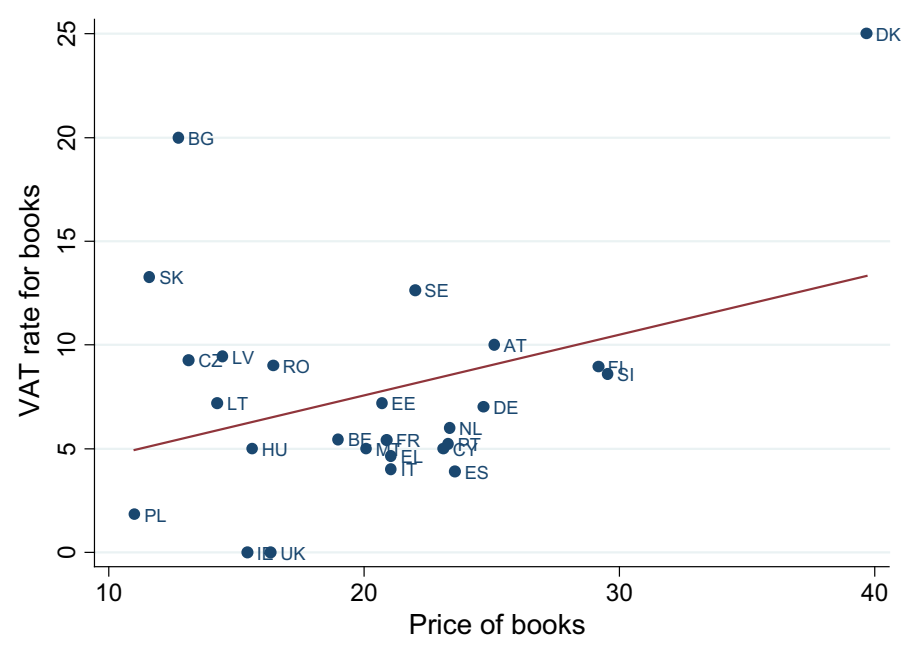

Fig. 4 Prices and VAT rate for books, average for 2003-2013, by country

of countries that had relatively high VAT rates for books and to increases in individual countries.

Next, we visualize the correlation between VAT rates for books and prices in Fig. 4. Since the price data are not available for the same extended time period as the fiscal rates, the correlation is shown for the years from 2003 to 2013 only. The association is found to be positive: countries with a higher VAT rate for books have higher book prices in general. This is in agreement with the expected effect of a VAT on price from the theoretical model. The Nordic countries (Denmark, Sweden, Finland and Norway) have the highest rates and also prices - thus appearing in the upper right segment. The UK and Ireland appear at the other end of the spectrum, having the lowest rates and also rather low prices. This may partially be due to the market size of books in English, compared to other European languages. Central, Western and Southern Europe exhibit about average prices and mid-range tax rates, with the latter ones (Italy, Cyprus, Portugal, Spain and Malta) having tax rates typically below those of most of Central Europe (Austria, Germany, Netherlands) and France. The Eastern part of the EU (most of the accession members of 2004 and 2007) exhibit the lowest prices, which is likely due to the comparatively low economic welfare in those countries; however, fiscal rates are rather widely spread, with Bulgaria and Slovakia being the outliers in terms of high rates, while Poland and Hungary exhibit below average rates. The positive correlation between prices and VAT rate for books can be found per country in Fig. 7, highlighting the country variations.

It is true that the VAT rate does not exhibit very high volatility and in some few countries (e.g. Denmark) does not change at all over the studied time period. In other countries, however, it does see variation: in Greece it is gradually rising over time, whereas in Latvia there can be observed a peak before the rate falls somewhat. This is also why the VAT rate for books has a relatively high standard deviation of 6.01 (with a mean of 7.08, Table 1) and should be regarded as sufficient variation for the aims of this paper. 


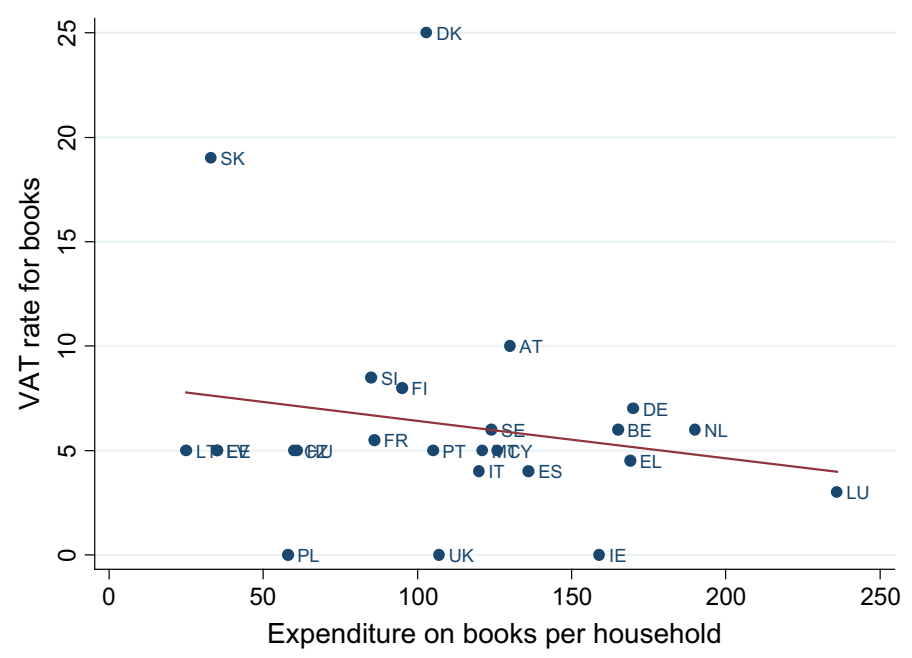

Fig. 5 Expenditure on books per household and VAT rate for books, 2005, by country

We turn next to a comparison of VAT rates for books with household expenditure on books by country. The theoretical model proposes that a greater VAT rate leads to a lower household expenditure as the total price to the consumer rises. Using the variable for the year 2005, the most recent year for which book expenditure is known, the correlations are shown in Fig. 5. The association is negative implying that household expenditure on books is increasing as the VAT rate for books decreases, as theory predicted. Appendix contains a country-specific figure where we see some geographical variation (see Fig. 7).

Some Central European countries (Luxembourg, Germany, Netherlands, Belgium) exhibit the highest expenditure in the range of 170-240 euros per household in 2005. Southern Europe and France have rather similar expenditure patterns to the Nordic Countries (however, here we have Denmark with a very high VAT rate of $25 \%$ ). The Baltic countries, Poland, the Czech Republic and Slovakia show the lowest household expenditure.

Contrary to expectation, use of e-commerce to purchase books in 2008 shows an insignificant correlation with VAT rates (see Fig. 6). Books have become an important segment of the online market, and Internet retailers can offer over two million book titles to consumers who increasingly benefit from online product reviews (Benhamou 2015). It was thus expected that online consumers would respond positively to lower VAT book rates, but results may reflect other variables such as Internet access penetration, digital literacy, diversity of demand or title availability in a particular language. Furthermore, the available data for 2008 covers a period when e-commerce was still relatively underdeveloped. This may change as the market for e-books grows in Europe and as the VAT for e-books is set to match the paper counterpart.

The presented graphical illustrations appear to be consistent with theory and allow an intuitive interpretation of the main patterns. However, the correlations 


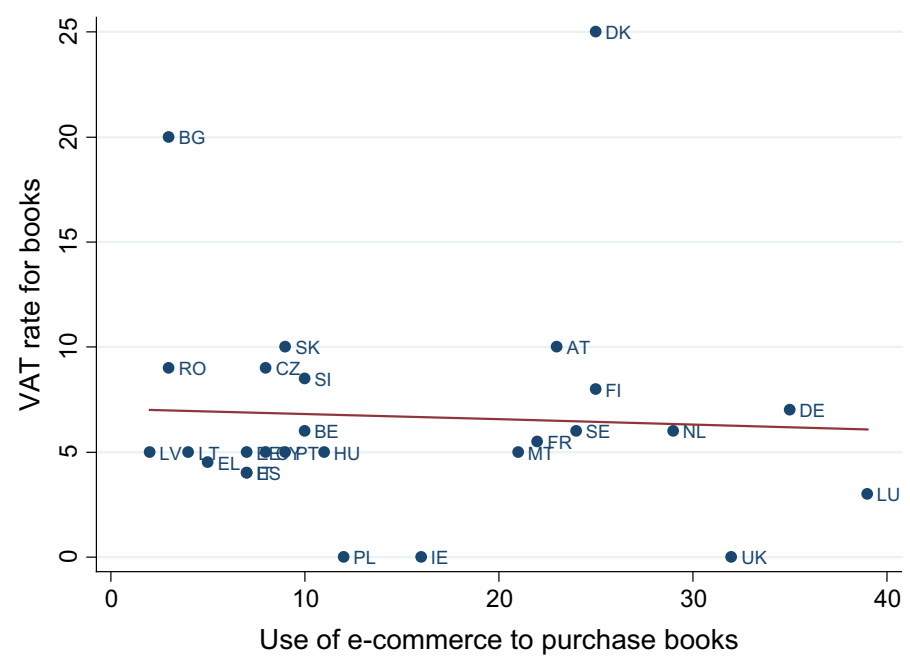

Fig. 6 Use of e-commerce to purchase books and VAT rate for books, 2008, by country. Note use of e-commerce to purchase books is measured with the share of individuals who purchased one or more books online in the last 3 months (Eurostat 2015)

could be biased due to the many unobserved differences across countries and over time. Furthermore, a correlation does not imply a causal relationship. Therefore, we next turn to a more formal, econometric exploration of the data.

\section{Results}

In this section we present the analysis of VAT rates in three parts. First, we explore what are the determinants of VAT rates. Second, we study the association between VAT rates for books and book prices. Third, we analyse the effect a lower VAT rate may have on the book expenditure of households.

\subsection{Correlates of VAT rates}

We first estimate a simple model, in which we explore the correlates of various types of the standard and reduced VAT rates for cultural goods and services. The estimations include the previously introduced key socio-economic variables that determine cultural consumption: population size, wealth of a country measured according to GDP per capita and educational attainment.

We use a linear regression model that includes both year and country fixed effects in order to capture unobserved differences over time as well as across countries. The results for the standard and a set of reduced VAT rates for cultural goods and services are shown in Table 2. Higher GDP per capita, larger populations or a lower level of education is associated with a lower standard VAT rate (column 1). 


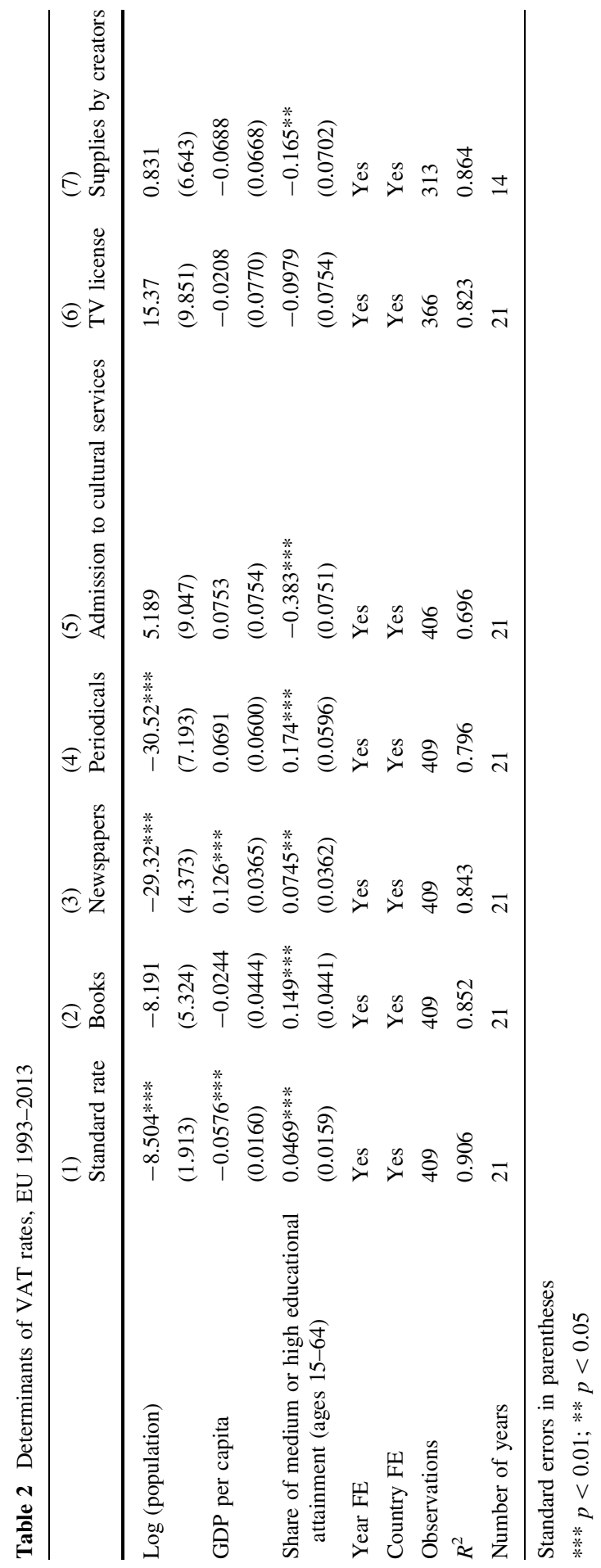


In this table, we also explore whether the setting of VAT rates for cultural goods and services is governed by similar fundamentals across countries. We illustrate the correlates for VAT rates for books (column 2) as well as for other cultural goods: newspapers, periodicals, admission to cultural services, TV license and services by writers, composers and performing artists (columns 3-7, respectively).

The only significant correlation found for the VAT rate for books is with educational attainment and, interestingly, the point estimate is positive. This is possibly attributable to the fact that countries with a higher educational level do not need a stimulus for the consumption of books and can therefore set a higher VAT rate. Such is the case of Denmark, where books have no reduced VAT rate and instead universities receive a refund of the paid VAT (Hemels 2009). The reduced VAT rate, which is arguably a measure to increase access to books and improve literacy or education (Canoy et al. 2006), is not required in well-educated countries. The associations between the VAT rate for books and population or wealth are insignificant.

Higher fiscal rates also apply to newspapers and periodicals in better educated countries, or in smaller and poorer countries. However, in countries characterized by high educational attainment VAT rates are lower for admission to cultural services and for services by writers, composers and performing artists.

The emerging results are interesting. While VAT rates are related to the fundamental socio-economic variables employed (population size, wealth and education), there is no clear pattern found in relation to most of the cultural fiscal rates. The small, albeit important, set of regressors does not exhibit any clear, consistent associations across the different cultural goods and services. This suggests that these VAT rates are set independently from the fundamental drivers of cultural consumption, or that these rates are governed by other unobservable factors.

This is obviously a basic model that considers only the fundamental determinants of cultural consumption, and not a range of other socio-economic variables whose inclusion would be arbitrary and difficult to motivate. However, one may be concerned about the role of politics in the tax setting decisions. In particular, the use of a consumption tax policy to redistribute resources has been linked to left-wing political parties (Beramendi and Rueda 2007). Therefore, in a robustness test we control for the party orientation with respect to economic policy. We include a dummy variable that takes the value one if in a given year the country was governed by a left-wing party (as defined by Keefer 2012), and zero otherwise. The additional variable is intended to account for the fundamental difference in political attitudes towards fiscal regulation across the political spectrum. ${ }^{6}$ The results of this test are presented in Appendix 3. The point estimates for the fundamental determinants are very consistent in sign and typically also in size and statistical significance level. Whereas the correlation coefficients for the left-wing party orientation are usually statistically insignificant and hence inconclusive. This could be related to the fact

\footnotetext{
${ }^{6}$ We have also tried to estimate the political spectrum in other ways, for example, by controlling for right-wing parties as well. In Denmark, for example, right-oriented political parties favour less taxation as an indirect form of welfare reduction, according to Klitgaard and Elmelund-Praestekaer (2014).
} 
that leftists are reluctant to indirect taxes, such as the VAT that are less redistributive than direct taxes, especially income taxes.

\subsection{VAT rates and prices}

Next, we turn to an estimation of the relationship between prices of cultural goods and fiscal rates, and present the regression results in Table 3. The available data allow us to study these associations for books (column 1) as well as for museum, opera and cinema tickets (columns 2-4, respectively). Since the utilized price series is available only for the period 2003-2013, the regressions are based on a somewhat lower number of observations. Again, the models include year and country fixed effects; the former are particularly important in this case, since the price series for each year is based on a different product (the same one across countries, however). Year fixed effects thus account for the unobservable differences across these specific products.

The point estimates are positive and statistically significant for the case of books, museum tickets and opera tickets. This implies that VAT rates tend to have a positive relation to the actual prices of these particular goods, which is in line with the theoretical prediction of an effect of a reduced VAT rate on price. A decrease in the VAT rate for books of one percentage point indicates that prices drop by 0.5 euro; given the mean book price of 19.3 euros, the decrease in about $2.6 \%$ is also economically significant. There is no significant association found for the cinema category, which is possibly caused by the remarkable concentration in this industry.

Table 3 Reduced VAT rates and prices, EU 2003-2013

\begin{tabular}{|c|c|c|c|c|}
\hline & $\begin{array}{l}\text { (1) } \\
\text { Book price }\end{array}$ & $\begin{array}{l}\text { (2) } \\
\text { Museum } \\
\text { price }\end{array}$ & $\begin{array}{l}(3) \\
\text { Opera } \\
\text { price }\end{array}$ & $\begin{array}{l}(4) \\
\text { Cinema } \\
\text { price }\end{array}$ \\
\hline VAT rate for books & $\begin{array}{l}0.504 * \\
(0.260)\end{array}$ & & & \\
\hline VAT rate for admission to cultural services & & $\begin{array}{l}0.0685 * \\
(0.0380)\end{array}$ & $\begin{array}{l}0.570 * * \\
(0.242)\end{array}$ & $\begin{array}{l}-0.0187 \\
(0.0303)\end{array}$ \\
\hline Log (population) & $\begin{array}{l}1.026 \\
(1.285)\end{array}$ & $\begin{array}{l}0.290 \\
(1.442)\end{array}$ & $\begin{array}{l}155.4 * * * \\
(48.56)\end{array}$ & $\begin{array}{l}13.02 * * \\
(4.134)\end{array}$ \\
\hline GDP per capita & $\begin{array}{l}0.643 * * * \\
(0.160)\end{array}$ & $\begin{array}{l}0.597 * * * \\
(0.166)\end{array}$ & $\begin{array}{l}2.875 * * * \\
(0.611)\end{array}$ & $\begin{array}{l}0.341 * * \\
(0.107)\end{array}$ \\
\hline $\begin{array}{l}\text { Share of medium or high educational attainment } \\
\text { (ages 15-64) }\end{array}$ & $\begin{array}{l}-0.455^{* * * *} \\
(0.101)\end{array}$ & $\begin{array}{l}0.164 \\
(0.202)\end{array}$ & $\begin{array}{l}-0.391 \\
(0.467)\end{array}$ & $\begin{array}{l}0.0561 \\
(0.0716)\end{array}$ \\
\hline Year FE & Yes & Yes & Yes & Yes \\
\hline Country FE & Yes & Yes & Yes & Yes \\
\hline Observations & 169 & 172 & 178 & 180 \\
\hline$R^{2}$ & 0.692 & 0.735 & 0.858 & 0.760 \\
\hline Number of years & 10 & 10 & 10 & 10 \\
\hline
\end{tabular}

Standard errors in parentheses

$* * * p<0.01$; ** $p<0.05$; * $p<0.1$ 
Western movie markets are dominated by six media conglomerates whose various film production and distribution subsidiaries collectively command approximately $80-85 \%$ of box office revenue (Bettig and Hall 2012). A possible consequence of this market power is that any benefit from a tax decrease is not transformed over to the cinema consumer, but retained by the supplier.

Out of the socio-economic controls, population size and GDP per capita are found to be consistently positive and mostly turn out to be statistically significant. The education measure is estimated with less precision; it is significant and negative only for the case of book prices, implying that a less educated population coincides with higher book prices, all else equal.

\subsection{VAT rates for books and expenditure}

Next, we turn to the estimation of the effect of a fiscal reduction on a household's expenditure on books. Table 4 shows the associated cross-section results using data for the available year 2005 (for which book expenditure is known). The model estimates how book expenditure depends on the VAT rates for books, and all three fundamental determinants of cultural consumption are included (i.e. population, wealth and education). The correlation is found to be negative (column 1), indicating that for a one percentage point higher VAT rate for books, households spend 2.18 euros less on books, on average.

Table 4 The casual impact of reduced rates on book expenditure

\begin{tabular}{llll}
\hline Variables & $\begin{array}{l}(1) \\
\text { Expenditure } \\
\text { books } \\
\text { OLS }\end{array}$ & $\begin{array}{c}(2) \\
\text { VAT rate for } \\
\text { books first-stage } \\
\text { OLS }\end{array}$ & $\begin{array}{c}\text { (3) } \\
\text { Expenditure } \\
\text { books } \\
\text { IV }\end{array}$ \\
\hline Standard VAT rate & & $0.467 * * *$ & $(0.145)$ \\
VAT rate for books & $-2.179 *$ & & $-2.778^{* *}$ \\
Log (population) & $(1.262)$ & $-4.303)$ \\
GDP per capita & -0.390 & -4.218 & -0.839 \\
Share of medium or high educational & $(4.508)$ & $(5.398)$ & $(4.379)$ \\
attainment (ages 15-64) & $3.518 * * *$ & 0.00246 & $3.442 * * *$ \\
Observations & $(0.568)$ & $(0.0446)$ & $(0.549)$ \\
$R^{2}$ & -0.716 & $0.127 * * *$ & -0.644 \\
Cragg-Donald eigenvalue statistics & $(0.485)$ & $(0.0441)$ & $(0.468)$ \\
Number of years & 25 & 409 & 25 \\
\hline Stang & 0.693 & 0.856 & 0.712
\end{tabular}

Standard errors in parentheses

*** $p<0.01$; ** $p<0.05 ; * p<0.1$ 
However, this is only the correlation, and it gives us little information about the causal effect. The correlation estimate could be biased due to endogeneity. It could be the case that the effect is the opposite: countries with high cultural consumption decide to implement lower VAT rates. Alternatively, the point estimates could be biased due to omitted variables, such as, for example, unobservable country-specific preferences for culture. Therefore, we extend the OLS regression by an instrumental variable model in order to shed light on the causal effects.

We use the entire time series of the standard VAT rate as an instrument for VAT rates for books. The standard VAT rate is arguably exogeneous to the VAT rates for books, as it is decided upon by the policy makers without consideration of household expenditure on books. And yet, reduced VAT rates for books are related to the standard VAT rate, as they are typically set by each individual country in proportion to the regular VAT rate (EC 2006). ${ }^{7}$ The first-stage estimation, which includes year and country fixed effects, shows this to be the case (column 2). Instrumenting for the VAT rate for books delivers a negative and significant IV coefficient (column 3). This implies that a lower VAT rate on books has a causal impact on book expenditure. Considering the average household's expenditure on books of 102.3 euros per year, the coefficient implies that a one percentage point decrease in the reduced rate for books leads to an increase in expenditure by about $2.7 \%$. This result is consistent with theory. Furthermore, by building on data for a wide set of EU Member States, we find strong support of the notion that cultural consumption can be triggered by the right fiscal discounts.

\section{Conclusions}

Fiscal policy is an important part of cultural policy that receives less attention than deserved, in particular the VAT rate discounts on cultural consumption even though it represents a significant cost (due to revenue loss) with highly diffused results (no target good, consumer or provider). This may be due to the lack of research to explain the impact of national measures on household consumption. In this article we shed some light on whether (and how) fiscal policy stimulates the consumption of Europe's cultural heritage.

We document standard and reduced fiscal rates for books and other cultural goods and services in the EU Member States since 1993. In an attempt to generate a quantitative indication on how fiscal rates are set, we estimate their correlates. The results, however, do not deliver any clear patterns, as if there was no systematic association between reduced rates for culture and the fundamental drivers of cultural consumption. We further estimate the relation between VAT rates for books and book prices or household expenditure on books. We show that the exact relation is that a $1 \%$ decrease in the VAT rate results in a $2.7 \%$ increase in book expenditure. These results reinforce the theory of lower prices and increased consumption due to a reduced VAT rate.

\footnotetext{
7 It would be interesting to include book price controls into these regressions to disentangle direct effects of VAT on expenditure and the indirect effects through price changes. However, this would decrease the number of observations to seven, which is insufficient for the estimation of an econometric model with the needed regressors.
} 
An in-depth analysis of the historic characteristics in each country may provide a more holistic explanation of the findings, for instance, including country-specific cultural consumption preference for substitute cultural goods (e.g. books, opera, film), or country-specific policies to encourage production (e.g. various forms of support for film production). Book differentiation, including hard cover and paperback but perhaps also subject or genre, may highlight the specifics of consumer preference and price elasticity. Further research is also needed to compare our results to the impact of VAT rates for other cultural goods, such as performing arts, heritage or the creative industries as well as research on the increasingly digital consumption of cultural goods. Comparing the effect of a reduced VAT rate and that of a direct subsidy may highlight the strengths and weaknesses of each fiscal measure to achieve the desired goals. Due to the positive externalities associated with cultural consumption, markets fail to provide the optimum quantity of culture at the right price. Book consumption, specifically, increases literacy in turn associated with intelligent decision-making. Tax instruments are thus proposed by welfare theory as effective tools that can be used to change the quantities and prices, in order to tackle market failures. From a policy perspective, this suggests that a reduction in VAT rates can stimulate household consumption, though with unequal benefit for the different socio-economic groups, and should consequently be designed in conjunction with a national cultural policy.

In our society, changes brought on by digital technology have a highly dynamic nature, as consumer behaviour responds to and influences the adoption of new forms of production, distribution and consumption of heritage. Many effects of newly adopted consumption patterns will be tangible in the long term, as future generations are able (or not) to ensure sustainable access to materials (e.g. Marty 2008). One already visible change is the exponential growth in customer reach through the Internet (e.g. Bakhshi and Throsby 2012). In this paper, it is shown that fiscal policy can potentially support a cultural policy aimed at increasing and enhancing audience reach. It is hoped that this will be increasingly recognized by European policy makers, especially nowadays at the onset of the age of digitization, where right and efficient policy lines may have significant consequences for future developments.

Acknowledgements Funding was provided by the European Commission (grant agreement number 612789, part of the RICHES Project, Renewal, Innovation and Change: Heritage and European Society).

Open Access This article is distributed under the terms of the Creative Commons Attribution 4.0 International License (http://creativecommons.org/licenses/by/4.0/), which permits unrestricted use, distribution, and reproduction in any medium, provided you give appropriate credit to the original author(s) and the source, provide a link to the Creative Commons license, and indicate if changes were made.

\section{Appendices}

\section{Appendix 1: VAT directive in the European Union}

VAT was first introduced in France in 1954, and by 1967 the European Union established a VAT system, which became a prerequisite for membership. Over 80 countries have adopted the VAT system (CE 2007), including all OECD countries, 
except for the USA where most states raise revenue through a sales tax. Before the VAT system was established, governments used the retail sales tax to raise revenue (Charlet and Owens 2010). The VAT system is favoured over a sales tax because it reduces fraud, it does not reduce the incentives to save or invest and it allows setting various rates of taxation to different goods and services (CE 2007). VAT is a tax defined not by the individual's ability to pay, as is the personal income tax, but on her ability to consume.

VAT rates are harmonized across EU Member States through a set of guidelines defined in the European Commission's Council Directive 2006/112/EC of 28 November 2006 on the common system of value added tax (OJ 2006 L 347, p. 1), as amended by Council Directive 2010/88EU of 7 December 2010 (OJ 2010 L 326, p. 1). Annex III to that directive contains a list of the goods and services that may receive a reduced rate and annex IX contains a list specific to works of art. Point 6 of Annex III to the VAT Directive includes the supply of books "on all physical means of support" while article 7(1) and (2) of Implementing Regulation No 282/2011 excludes "electronically supplied services" (e.g. e-books). That is, the VAT rate is established based on the carrier and not on the content, resulting in a negative incentive for technologic development in Europe. "The current VAT regime [translates in] a competition advantage for printed" materials (Hemels 2009, p. 14).

The VAT Directive states that the minimum standard rate may not be less than 15\%; reduced rates should not be less than 5\%; some EU Member States may maintain a super reduced rate that is lower than 5\% (EC 2006), and in other cases goods may have a VAT exemption all together. EU Member States decide whether a VAT reduced rate is allocated to goods and services, from the list in Annex III and IX of the VAT Directive. The nature of cultural goods and services has resulted too broad when defining VAT rates, as VAT rates only apply to goods and not to services and as such excludes things such as video art and commissioned work. Not all Member States have the same reduction on specific goods and services since VAT rates are part of a national tax policy and may function to complement the government financing system towards culture in different ways (Colbjørnsen 2014). France and Luxembourg are two EU countries that introduced a reduced VAT rate also for e-books on 1 January 2012, at 5.5 and 3\%, respectively, without the Commission's approval. The Court of Justice of the European Union ruled on 5 March 2015 that e-books supplied via download or streaming to be a service and therefore fall outside of the VAT exemption. France and Luxemburg are required to comply with the VAT Directive.

The increased use of digital technology for the production, distribution and consumption of cultural goods and services has raised questions regarding the VAT Directive. Besides the distinction on carrier instead of content to define a VAT rate (as the case of e-books), the geographical location has proved important to determine the VAT rate, as fiscal policy is set within individual EU Member States. The Internet allows the producer, distributer and consumer to be located in different locations and therefore be regulated by different VAT rates, giving a market advantage to certain Internet-based suppliers (namely Luxemburg-based suppliers) (Campbell 2013). On 1 January 2015, a change in the VAT Directive was 
established to define taxation on the basis of the location of the end customer and not, as previously established, based on the location of the supplier. This lead to the Council Directive Proposal for the Action Plan on VAT [COM(2016) 148 final] to amend the Directive 2006/112/EC for it to be in line with the Commission's Digital Single Market Strategy [COM(2015) 0192 final]. In the proposal, electronically supplied publications (books, newspapers and periodicals) "should be able to benefit from the same preferential VAT rate treatment as publications on any means of physical support" but should not include audio-visual content (music or video) [amending Annex III, point (6)].

\section{Appendix 2: Overview of VAT rates by country, 1993-2013}

See Fig. 7.

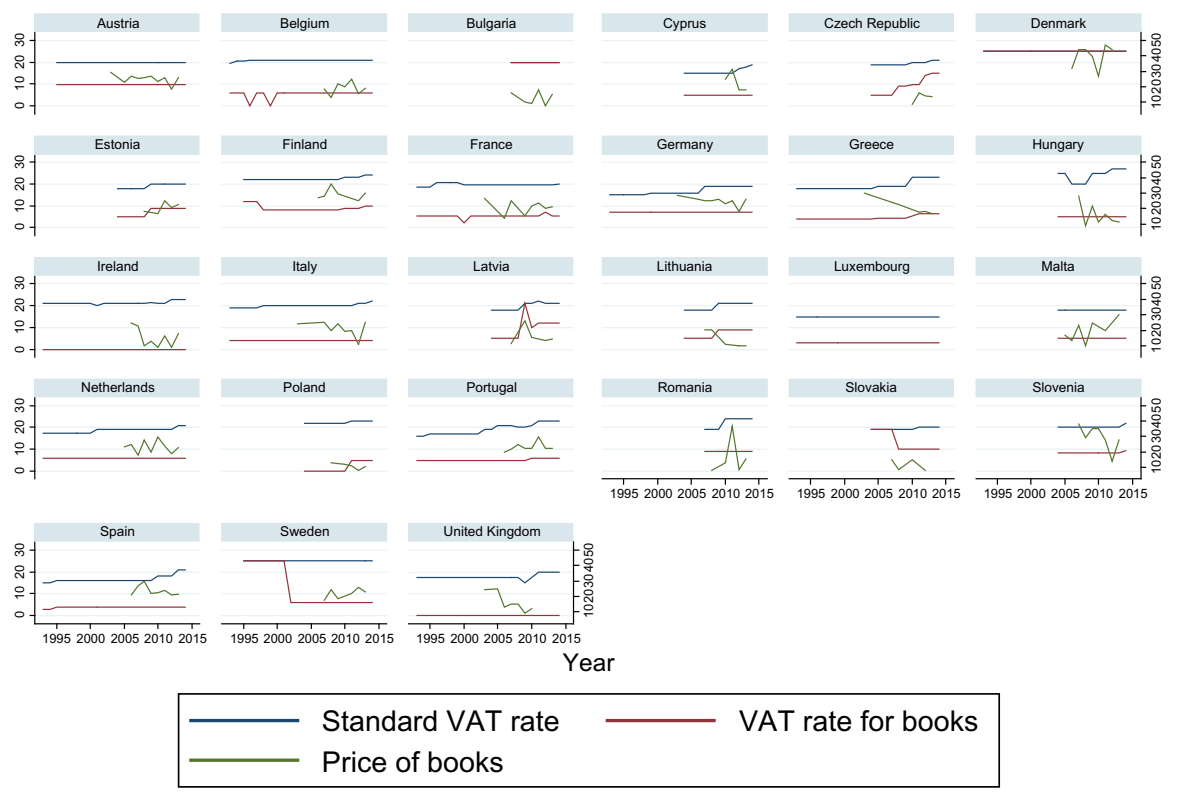

Fig. 7 VAT rate for books and prices, by country

\section{Appendix 3: Additional tables and figures}

See Tables 5, 6, 7 and 8 . 


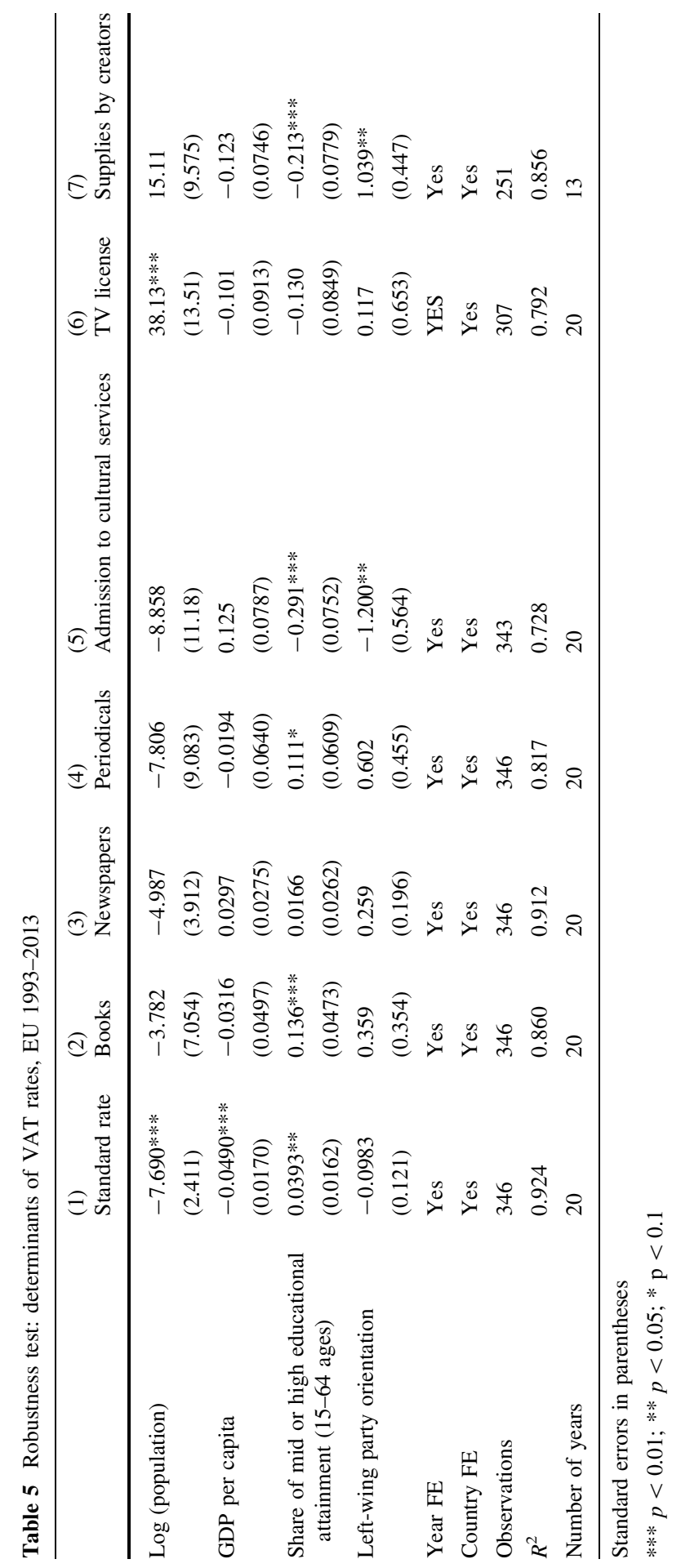


Table 6 E-book markets in the EU-5, 2008-2014 (billion euros). Data source: European Commission, analysis of the media and content industries: the publishing industry 2012

\begin{tabular}{lrrrrrrr}
\hline & 2008 & 2009 & 2010 & 2011 & 2012 & 2013 & 2014 \\
\hline Print & 17.6 & 17.5 & 17.2 & 16.9 & 16.5 & 16.2 & 16 \\
E-book & 0.1 & 0.2 & 0.4 & 0.6 & 1 & 1.3 & 1.6 \\
Total & 17.7 & 17.7 & 17.6 & 17.5 & 17.5 & 17.5 & 17.6 \\
E-book share (\%) & 0.6 & 1.1 & 2.3 & 3.6 & 6.1 & 8.0 & 10.0 \\
\hline
\end{tabular}

Table 7 Robustness test: reduced VAT rates and book prices, EU 2003-2009

\begin{tabular}{|c|c|c|}
\hline Variables & $\begin{array}{l}\text { (1) } \\
\text { Book price baseline } \\
\quad(1993-2014)\end{array}$ & $\begin{array}{l}\text { (2) } \\
\text { Book price until } \\
2010\end{array}$ \\
\hline red_book & $\begin{array}{l}0.504 * \\
(0.260)\end{array}$ & $\begin{array}{l}0.629 * \\
(0.260)\end{array}$ \\
\hline lpop & $\begin{array}{l}1.026 \\
(1.285)\end{array}$ & $\begin{array}{l}1.585 \\
(1.317)\end{array}$ \\
\hline gdp_pc & $\begin{array}{l}0.643 * * * \\
(0.160)\end{array}$ & $\begin{array}{l}0.929 * * \\
(0.305)\end{array}$ \\
\hline educ_15_64_mid_high & $\begin{array}{l}-0.455^{* * *} \\
(0.101)\end{array}$ & $\begin{array}{l}-0.597 * * * \\
(0.113)\end{array}$ \\
\hline o.country1 & - & - \\
\hline o.country 2 & - & - \\
\hline Country3 & $\begin{array}{l}4.647 * \\
(2.071)\end{array}$ & $\begin{array}{l}6.001 * * \\
(2.236)\end{array}$ \\
\hline $\begin{array}{l}\text { o.country4 } \\
\text { country5 }\end{array}$ & $\begin{array}{l}- \\
-2.825 \\
(2.645)\end{array}$ & $\begin{array}{l}- \\
-3.765 \\
(4.062)\end{array}$ \\
\hline $\begin{array}{l}\text { o.country6 } \\
\text { country } 7\end{array}$ & $\begin{array}{l}- \\
5.328 \\
(4.318)\end{array}$ & $\begin{array}{l}- \\
10.15 \\
(6.254)\end{array}$ \\
\hline o.country 8 & - & - \\
\hline o.country 9 & - & - \\
\hline country10 & $\begin{array}{l}15.05^{* *} \\
(6.542)\end{array}$ & $\begin{array}{l}20.96 * * * \\
(5.185)\end{array}$ \\
\hline country11 & $\begin{array}{l}8.909 * \\
(4.169)\end{array}$ & $\begin{array}{l}12.81 * * \\
(4.500)\end{array}$ \\
\hline country 12 & $\begin{array}{l}4.203 \\
(5.473)\end{array}$ & $\begin{array}{l}-2.822 \\
(5.641)\end{array}$ \\
\hline country 13 & $\begin{array}{l}20.26 * * * \\
(6.115)\end{array}$ & $\begin{array}{l}26.75 * * * \\
(6.322)\end{array}$ \\
\hline $\begin{array}{l}\text { o.country } 14 \\
\text { country } 15\end{array}$ & $\begin{array}{l}- \\
10.64 * * * \\
(1.693)\end{array}$ & $\begin{array}{l}- \\
11.66 * * * \\
(1.292)\end{array}$ \\
\hline
\end{tabular}


Table 7 continued

\begin{tabular}{|c|c|c|}
\hline Variables & $\begin{array}{l}\text { (1) } \\
\text { Book price } \\
\text { baseline (1993-2014) }\end{array}$ & $\begin{array}{l}\text { (2) } \\
\text { Book price } \\
\text { until } 2010\end{array}$ \\
\hline country 16 & $\begin{array}{l}-1.112 \\
(1.969)\end{array}$ & $\begin{array}{l}-2.671 \\
(3.023)\end{array}$ \\
\hline o.country17 & - & - \\
\hline country 18 & $\begin{array}{l}6.601 * * \\
(2.493)\end{array}$ & $\begin{array}{l}7.800 * * \\
(2.439)\end{array}$ \\
\hline country 19 & $\begin{array}{l}5.685 * \\
(3.045)\end{array}$ & $\begin{array}{l}10.06 * * \\
(3.197)\end{array}$ \\
\hline country 20 & $\begin{array}{l}13.10^{*} \\
(6.371)\end{array}$ & $\begin{array}{l}21.71 * * * \\
(5.706)\end{array}$ \\
\hline $\begin{array}{l}\text { o.country } 21 \\
\text { country } 22\end{array}$ & $\begin{array}{l}- \\
-4.762 \\
(4.383)\end{array}$ & $\begin{array}{l}- \\
-6.826 \\
(6.907)\end{array}$ \\
\hline country 23 & $\begin{array}{l}-4.191 * \\
(2.202)\end{array}$ & $\begin{array}{l}-5.317 \\
(2.854)\end{array}$ \\
\hline country 24 & $\begin{array}{l}13.99 * * \\
(5.793)\end{array}$ & $\begin{array}{l}22.30 * * \\
(7.029)\end{array}$ \\
\hline $\begin{array}{l}\text { o.country } 25 \\
\text { country } 26\end{array}$ & $\begin{array}{l}- \\
15.52 * * \\
(6.398)\end{array}$ & $\begin{array}{l}- \\
27.25 * * \\
(7.735)\end{array}$ \\
\hline $\begin{array}{l}\text { o.country } 27 \\
\text { o.country } 28 \\
\text { country } 29\end{array}$ & $\begin{array}{l}- \\
- \\
-1.149 \\
(9.402)\end{array}$ & $\begin{array}{l}- \\
- \\
-1.457 \\
(9.856)\end{array}$ \\
\hline o.country 30 & - & - \\
\hline $\begin{array}{l}\text { o.country } 31 \\
\text { country32 }\end{array}$ & $\begin{array}{l}- \\
0.409 \\
(1.810)\end{array}$ & $\begin{array}{l}- \\
-0.0365 \\
(2.728)\end{array}$ \\
\hline $\begin{array}{l}\text { o.country } 33 \\
\text { country } 34\end{array}$ & $\begin{array}{l}- \\
11.58 * \\
(5.148)\end{array}$ & $\begin{array}{l}- \\
23.06 * * \\
(6.366)\end{array}$ \\
\hline country35 & $\begin{array}{l}-2.660 \\
(4.115)\end{array}$ & $\begin{array}{l}-5.836 \\
(4.444)\end{array}$ \\
\hline country36 & $\begin{array}{l}11.25 \\
(6.477)\end{array}$ & $\begin{array}{l}12.26^{*} \\
(5.951)\end{array}$ \\
\hline o.country 37 & - & - \\
\hline o.country38 & - & - \\
\hline o.country39 & - & - \\
\hline country40 & $\begin{array}{l}9.187 \\
(5.156)\end{array}$ & $\begin{array}{l}16.55^{* *} \\
(6.071)\end{array}$ \\
\hline country41 & $\begin{array}{l}23.62 * * * \\
(5.906)\end{array}$ & $\begin{array}{l}33.88 * * * \\
(4.176)\end{array}$ \\
\hline
\end{tabular}


Table 7 continued

Robust standard errors in parentheses

*** $p<0.01$; ** $p<0.05$;

$* p<0.1$

Table 8 Robustness test: reduced VAT rates and book prices, controlling for nationality of book author, EU 2003-2009

\begin{tabular}{lll}
\hline Variables & $\begin{array}{l}(1) \\
\text { Book price baseline } \\
(1993-2014)\end{array}$ & $\begin{array}{l}(2) \\
\text { Book price } \\
\text { until 2010 }\end{array}$ \\
\hline Constant & 11.82 & 2.987 \\
& $(27.40)$ & $(27.52)$ \\
Observations & 169 & 102 \\
$R^{2}$ & 0.692 & 0.763 \\
Number of year & 10 & 7 \\
\hline
\end{tabular}

\begin{tabular}{|c|c|c|}
\hline Variables & $\begin{array}{l}\text { (1) } \\
\text { Book price } \\
\text { baseline }\end{array}$ & $\begin{array}{l}\text { (2) } \\
\text { Book price }\end{array}$ \\
\hline red_book & $\begin{array}{l}0.504 * \\
(0.260)\end{array}$ & $\begin{array}{l}0.500 * \\
(0.259)\end{array}$ \\
\hline lpop & $\begin{array}{l}1.026 \\
(1.285)\end{array}$ & $\begin{array}{l}0.383 \\
(1.365)\end{array}$ \\
\hline gdp_pc & $\begin{array}{l}0.643 * * * \\
(0.160)\end{array}$ & $\begin{array}{l}0.609 * * * \\
(0.144)\end{array}$ \\
\hline educ_15_64_mid_high & $\begin{array}{l}-0.455^{* * * *} \\
(0.101)\end{array}$ & $\begin{array}{l}-0.474 * * * \\
(0.101)\end{array}$ \\
\hline o.country1 & - & - \\
\hline $\begin{array}{l}\text { o.country } 2 \\
\text { country } 3\end{array}$ & $\begin{array}{l}- \\
4.647 * \\
(2.071)\end{array}$ & $\begin{array}{l}- \\
4.497 * \\
(2.096)\end{array}$ \\
\hline $\begin{array}{l}\text { o.country4 } \\
\text { country5 }\end{array}$ & $\begin{array}{l}- \\
-2.825 \\
(2.645)\end{array}$ & $\begin{array}{l}- \\
-3.074 \\
(2.653)\end{array}$ \\
\hline $\begin{array}{l}\text { o.country6 } \\
\text { country } 7\end{array}$ & $\begin{array}{l}- \\
5.328 \\
(4.318)\end{array}$ & $\begin{array}{l}- \\
4.048 \\
(4.512)\end{array}$ \\
\hline o.country8 & - & - \\
\hline o.country9 & - & - \\
\hline country 10 & $\begin{array}{l}15.05 * * \\
(6.542)\end{array}$ & $\begin{array}{l}12.77 * \\
(6.453)\end{array}$ \\
\hline country11 & $\begin{array}{l}8.909 * \\
(4.169)\end{array}$ & $\begin{array}{l}8.334 * \\
(4.167)\end{array}$ \\
\hline country 12 & $\begin{array}{l}4.203 \\
(5.473)\end{array}$ & $\begin{array}{l}3.958 \\
(5.518)\end{array}$ \\
\hline country 13 & $\begin{array}{l}20.26 * * * \\
(6.115)\end{array}$ & $\begin{array}{l}18.21 * * \\
(6.055)\end{array}$ \\
\hline o.country 14 & - & - \\
\hline
\end{tabular}


Table 8 continued

\begin{tabular}{|c|c|c|}
\hline Variables & $\begin{array}{l}\text { (1) } \\
\text { Book price } \\
\text { baseline }\end{array}$ & $\begin{array}{l}\text { (2) } \\
\text { Book price }\end{array}$ \\
\hline country 15 & $\begin{array}{l}10.64 * * * \\
(1.693)\end{array}$ & $\begin{array}{l}10.15 * * * \\
(1.704)\end{array}$ \\
\hline country 16 & $\begin{array}{l}-1.112 \\
(1.969)\end{array}$ & $\begin{array}{l}-0.295 \\
(1.229)\end{array}$ \\
\hline $\begin{array}{l}\text { o.country } 17 \\
\text { country } 18\end{array}$ & $\begin{array}{l}- \\
6.601 * * \\
(2.493)\end{array}$ & $\begin{array}{l}- \\
7.818 * * \\
(2.587)\end{array}$ \\
\hline country 19 & $\begin{array}{l}5.685 * \\
(3.045)\end{array}$ & $\begin{array}{l}4.906 \\
(2.851)\end{array}$ \\
\hline country20 & $\begin{array}{l}13.10^{*} \\
(6.371)\end{array}$ & $\begin{array}{l}12.15^{*} \\
(6.312)\end{array}$ \\
\hline $\begin{array}{l}\text { o.country } 21 \\
\text { country } 22\end{array}$ & $\begin{array}{l}- \\
-4.762 \\
(4.383)\end{array}$ & $\begin{array}{l}- \\
-5.411 \\
(4.564)\end{array}$ \\
\hline country 23 & $\begin{array}{l}-4.191 * \\
(2.202)\end{array}$ & $\begin{array}{l}-3.845 \\
(2.212)\end{array}$ \\
\hline country 24 & $\begin{array}{l}13.99 * * \\
(5.793)\end{array}$ & $\begin{array}{l}12.15^{* *} \\
(5.036)\end{array}$ \\
\hline $\begin{array}{l}\text { o.country } 25 \\
\text { country } 26\end{array}$ & $\begin{array}{l}- \\
15.52 * * \\
(6.398)\end{array}$ & $\begin{array}{l}- \\
13.98 * \\
(6.349)\end{array}$ \\
\hline $\begin{array}{l}\text { o.country } 27 \\
\text { o.country } 28 \\
\text { country } 29\end{array}$ & $\begin{array}{l}- \\
- \\
-1.149 \\
(9.402)\end{array}$ & $\begin{array}{l}- \\
- \\
-4.669 \\
(9.845)\end{array}$ \\
\hline o.country 30 & - & - \\
\hline $\begin{array}{l}\text { o.country } 31 \\
\text { country32 }\end{array}$ & $\begin{array}{l}- \\
0.409 \\
(1.810)\end{array}$ & $\begin{array}{l}- \\
0.560 \\
(1.818)\end{array}$ \\
\hline o.country33 & $\begin{array}{l}- \\
11.58 * \\
(5.148)\end{array}$ & $\begin{array}{l}- \\
11.59 * * \\
(5.052)\end{array}$ \\
\hline country34 & $\begin{array}{l}-2.660 \\
(4.115)\end{array}$ & $\begin{array}{l}-4.168 \\
(3.863)\end{array}$ \\
\hline country36 & $\begin{array}{l}11.25 \\
(6.477)\end{array}$ & $\begin{array}{l}10.54 \\
(6.273)\end{array}$ \\
\hline o.country37 & - & - \\
\hline o.country38 & - & - \\
\hline o.country39 & - & - \\
\hline country40 & $\begin{array}{l}9.187 \\
(5.156)\end{array}$ & $\begin{array}{l}8.107 \\
(4.876)\end{array}$ \\
\hline
\end{tabular}


Table 8 continued

\begin{tabular}{lll}
\hline Variables & $\begin{array}{l}(1) \\
\text { Book price } \\
\text { baseline }\end{array}$ & $\begin{array}{l}(2) \\
\text { Book price }\end{array}$ \\
\hline country41 & $\begin{array}{l}23.62 * * * \\
(5.906)\end{array}$ & $\begin{array}{l}22.00 * * * \\
(5.914)\end{array}$ \\
author_country & & 1.747 \\
Constant & 11.82 & $(3.053)$ \\
& $(27.40)$ & 24.91 \\
Observations & 169 & $(27.66)$ \\
$R^{2}$ & 0.692 & 169 \\
Number of year & 10 & 0.692 \\
\hline
\end{tabular}

\section{References}

Ahlmark, D. (2003). Cultural VAT on books: An evaluation of the first three years. Stockholm: Swedish Booksellers' Association and Swedish Publishers' Association.

Ateca-Amestoy, V. (2008). Determining heterogeneous behavior for theatre attendance. Journal of Cultural Economics, 32(2), 127-151.

Bakhshi, H., \& Throsby, D. (2012). New technologies in cultural institutions: Theory, evidence and policy implications. International Journal of Cultural Policy, 18(2), 205-222.

Barrell, R., \& Weale, M. (2009). The economics of a reduction in VAT. Fiscal Studies, 30(1), 17-30.

Belastingdienst. (2014). Tarieven en vrijstellingen. Available at http://www.belastingdienst.nl/wps/wcm/ connect/bldcontentnl/belastingdienst/zakelijk/btw/tarieven_en_vrijstellingen/ Accessed 24 September 2014.

Benhamou, F. (2015). Fair use and fair competition for digitized cultural goods: The case of eBooks. Journal of Cultural Economics. Published online 4 March 2015.

Beramendi, P., \& Rueda, D. (2007). Social democracy constrained: Indirect taxation in industrialized democracies. British Journal of Political Science, 37(4), 619-641.

Bettig, R. V., \& Hall, J. L. (2012). Big media, big money: Cultural texts and political economics (2nd ed., pp. 59-108). Lanham, MD: Rowman \& Littlefield.

Blundell, R. (2009). Assessing the temporary VAT cut policy in the UK. Fiscal Studies, 30(1), 31-38.

Borowiecki, K. J. (2015). Historical origins of cultural supply in Italy. Oxford Economic Papers, 67(3), 781-805.

Borowiecki, K. J., Navarrete, T. (2017). Digitization of heritage collections as indicator of innovation. Economics of Innovation and New Technology, 26(3), 227-246.

Borselli, F., Chiri, S., \& Romagnano, E. (2012). Patterns of reduced VAT rates in the European Union. International VAT Monitor, 23, 13-21.

Bruce, C. (1997). Seven faces of information literacy. Adelaide: AULSIB Press.

Campbell, L. (2013). EU lines up e-book VAT debate. The Bookseller. Published 21 October 2013. Available at http://www.thebookseller.com/news/eu-lines-e-book-vat-debate.

Canoy, M., van Ours, J. C., \& van der Ploeg, F. (2006). The economics of books. In Victor Ginsburgh \& David Throsby (Eds.), Handbook of the economics of art and culture (pp. 721-761). Amsterdam: Elsevier.

Carbonnier, C. (2005). Is tax shifting asymmetric? Evidence from the French VAT reforms, 1995-2000. PSE working papers no. 2005-34.

CE (Copenhagen Economics). (2007). Study on reduced VAT applied to goods and services in the member states of the European Union. Final report. 21 June 2007. Denmark.

Charlet, A., \& Owens, J. (2010). An international perspective on VAT. Tax Notes International, 59(12), 943-954.

Colbjørnsen, T. (2014). What is the VAT? The policies and practices of value added tax on ebooks in Europe. International Journal of Cultural Policy. Published online 7 April 2014. 
Compendium. (2015). Price levels on cultural goods and services (2003-2013). Consulted on January 2015 from http://www.culturalpolicies.net/web/statistics-markets.php.

Crossley, T., Low, H., \& Wakefield, M. (2009). The economics of a temporary VAT cut. Fiscal Studies, $30(1), 3-16$.

Dallongeville, J., et al. (2010). Increasing fruit and vegetable consumption: A cost-effectiveness analysis of public policies. European Journal of Public Health., 21(1), 69-73.

Doyle, C. (1992). Outcome measure for information literacy within the National Educational Goals of 1990. Final report to the National Forum on Information Literacy. Flagstaff, AZ: NFIL.

EC. (2014). Report of the Commission Expert Group on taxation of the digital economy. Brussels: Taxation and Customs Union, EC.

EC, European Commission. (2006). Council Directive 2006/112/EC of 28 November 2006 on the common system of value added tax. L347/1.

Eurostat. (2011). Cultural statistics pocketbook. Luxembourg: Publications Office of the European Union.

Eurostat. (2014). Taxation trends in the European Union. Consulted in November 2014 from http://ec. europa.eu/taxation_customs/resources/documents/taxation/gen_info/economic_analysis/tax_ structures/2014/report.pdf.

Eurostat. (2015). Community survey on ICT usage in households and by individuals. Consulted in November 2014 from http://appsso.eurostat.ec.europa.eu/nui/show.do?dataset=isoc_ci_in_h\&lang= en.

Feld, A., O'Hare, M., \& Schuster, M. (1983). Patrons despite themselves: Taxpayers and Tax policy. New York, NY: New York University Press.

Franssen, T., \& Velthuis, O. (2014). Making materiality matter: A sociological analysis of prices on the Dutch fiction book market, 1980-2009. Socio-Economic Review. Published online 8 August 2014, pp. $1-24$.

Frey, B. (2008). Cities, culture and happiness. ETHOS, World Cities Summit Issue. June 2008, pp. 102-111.

Frey, B., \& Steiner, L. (2012). Pay as you go: A new proposal for museum pricing. Museum Management and Curatorship, 27(3), 223-235.

Gesko, M. (2013). Factors influencing the microeconomic and fiscal effects of the reduced VAT on books. In European Financial Systems 2013. Proceedings of the 10th international scientific conference. Brno: Masaryk University, pp. 99-106. Available at http://is.muni.cz/do/econ/soubory/ konference/efs/Sbornik_2013.pdf.

Hemels, S. (2005). Door de muze omhelsd. Een onderzoek naar de inzet van belastingsubsidies voor kunst en cultuur in Nederland. Nijmegen: Wolf Legal Publishers.

Hemels, S. (2007). Papieren BTW-tijger op de elektronische snelweg. Nederlands Tijdschrijft voor Fiscaal Recht, 8(6), 1-5.

Hemels, S. (2009). Influence of different purposes of value added tax and personal income tax on an effective and efficient use of tax incentives: Taking tax incentives for the arts and culture as an example. In M. Lang, P. Melz, \& E. Kristoffersson (Eds.), Value added tax and direct taxation similarities and differences. Amsterdam: IBFD.

Hjorth-Andersen, C. (2000). A model of the Danish book market. Journal of Cultural Economics, 24(1), 27-43.

Keefer, P. (2012). DPI2010. Database of Political Institutions: Changes and Variable Definitions. Washington, DC: Development Research Group, World Bank.

Kirchberg, V. (1998). Entrance fees as a subjective barrier to visiting museums. Journal of Cultural Economics, 22(1), 1-13.

Klitgaard, M., \& Elmelund-Praestekaer, C. (2014). The partisanship of systemic retrenchment: Tax policy and welfare reform in Denmark 1975-2008. European Political Science Review, 6(1), 1-9.

Krashen, S., Lee, S., \& McQuillan, J. (2012). Is the library important? Multivariate studies at the national and international level. Journal of Language and Literacy Education, 8(1), 26-38.

Lazzaro, E., \& Frateschi, C. (2015). Couples' arts participation: Assessing individual and joint time use. Journal of Cultural Economics. First online, 29 December 2015, pp. 1-23.

Linklater, E. (2014). Neutrality of VAT rates under European law: All books are created equal, but some are more equal than others? Publishing Research Quarterly, 20(3), 300-312.

Lomas, U. (2010). German hoteliers fail to pass on VAT reduction. Law and Tax News. Available at http://www.lawandtax-news.com/asp/German_Hoteliers_Fail_To_Pass_On_VAT_Reduction 41129.html. 
Marty, P. (2008). Changing needs and expectations. In P. Marty \& B. Jones (Eds.), Museum informatics, people, information and technology in museums (pp. 181-186). New York, NY: Routledge.

Mol, S., \& Bus, A. (2011). To read or not to read: A meta-analysis of print exposure from infancy to early adulthood. Psychological Bulletin, 137(2), 267-296.

MvF (Ministerie van Financien). (2014). Evaluatie verhoging btw-tarief podiumhunsten. Letter AFP/ 2014/289 with annex. The Hague.

Navarrete, T., Borowiecki, K. J. (2016). Changes in cultural consumption: Ethnographic collections in Wikipedia. Cultural Trends, 25(4), 233-248.

Neuman, S., \& Moland, N. (2016). Book deserts: The consequences of income segregation on children's access to print. Urban Education. First published online 3 August 2016, pp. 1-26.

O'Hagan, J. (1995). National museums: To charge or not to charge? Journal of Cultural Economics, 19(1), 33-47.

O'Hagan, J. (1998). The state and the arts: An analysis of key economic policy issues in Europe and the United States. Cheltenham: Edward Elgar.

O'Hagan, J. (2003). Tax concessions. In R. Towse (Ed.), A handbook of cultural economics. Cheltenham: Edward Elgar.

Plaza, B. (2000). Evaluating the influence of a large cultural artifact in the attraction of tourism. The Guggenheim Museum Bilbao case. Urban Affairs Review, 36(2), 264-274.

Prieto-Rodríguez, J., \& Fernández-Blanco, V. (2006). Optimal pricing and grant policies for museums. Journal of Cultural Economics, 30(3), 169-181.

Prieto-Rodriguez, J., Romero-Jordan, D., \& Sanz-Sanz, J. F. (2005). Is a tax cut on cultural goods consumption actually desirable? A microsimulation analysis applied to Spain. Fiscal Studies, 26(4), 549-576.

Ringstad, V., \& Løyland, K. (2006). The demand for books estimated by means of consumer survey data. Journal of Cultural Economics, 30(2), 141-155.

Schuster, M. (2006). Tax incentives in cultural policy. In V. Ginsburgh \& D. Throsby (Eds.), Handbook of the economics of art and culture (pp. 1253-1298). Amsterdam: Elsevier.

Seaman, B. (2006). Empirical studies of demand for the performing arts. In V. Ginsburgh \& D. Throsby (Eds.), Handbook of the economics of art and culture (pp. 415-472). Amsterdam: Elsevier.

Statistics Netherlands. (2015). Consumentenprijzen; prijsindex 2006 $=100$. Available from statline.cbs.nl.

Towse, R. (2010). A textbook of cultural economics. Cambridge: Cambridge University Press.

Zavisca, Jane. (2005). The status of cultural omnivorism: A case study of reading in Russia. Social Forces, 84(2), 1233-1255. 